\title{
Australian primary school teachers' perceived barriers to and enablers for the integration of children's literature in mathematics teaching and learning
}

\author{
Sharyn Livy ${ }^{1}$ (D) Tracey Muir $^{2}$ (D) Natthapoj Vincent Trakulphadetkrai ${ }^{3}$ (D) \\ Kevin Larkin ${ }^{4}$ (D)
}

Accepted: 7 September 2021 / Published online: 24 September 2021

(C) The Author(s) 2021

\begin{abstract}
This qualitative survey study set out to investigate in-service and pre-service primary school teachers' perceived barriers to and enablers for the integration of children's literature in mathematics teaching and learning in an Australian educational context. While research over the past three decades have documented pedagogical benefits of teaching mathematics using children's literature, research into teachers' perceptions regarding the use of such resources is virtually non-existent. The study thus filled this research gap by drawing responses from open-ended survey questions of 94 in-service and 82 pre-service teachers in Australia. A thematic analysis revealed 13 perceived barriers classified under five themes with Lack of Pedagogical Knowledge and Confidence, and Time Constraint, representing $75 \%$ of all perceived barriers. Moreover, 14 perceived enablers were identified and classified under five themes with Pedagogical Benefits and Love of Stories representing around $70 \%$ of all perceived enablers. Findings also showed that most of the teachers in the study (around 75\%) never or infrequently used children's literature in their mathematics classrooms. The study highlights the role of professional learning and teacher training in ensuring that both in- and pre-service teachers have the necessary pedagogical knowledge, experience and confidence in using children's literature to enrich their mathematics teaching.
\end{abstract}

Keywords Children's literature $\cdot$ Story picture books $\cdot$ Mathematics learning and teaching · Teachers' perceptions $\cdot$ Mathematics teacher education

\section{Introduction}

The notion of using children's literature, particularly story picture books, to teach mathematics is well established (National Council of Teachers of Mathematics [NCTM], 1992, 2004, 2018). There is general consensus in the literature that there are many benefits associated with using story picture books to teach mathematical concepts and skills, including

Natthapoj Vincent Trakulphadetkrai

n.trakulphadetkrai@reading.ac.uk

Extended author information available on the last page of the article 
the facilitation of mathematical language and communication (e.g., Capraro \& Capraro, 2006; Edelman et al., 2019; Stites et al., 2020). Story picture books have the potential to motivate children, stimulate interest, provide a context for using mathematics to solve problems (NCTM, 2018), to develop mathematical skills, and to explore and investigate mathematical concepts (e.g., Rogers et al., 2015). In order for these benefits to be realised in the classroom, the use of children's literature as a pedagogical approach needs to be adopted by schools and teachers. ${ }^{1}$ There is thus the need to understand teachers' beliefs towards the integration of children's literature with mathematics as these in turn will influence the uptake and appropriate implementation of using children's literature as a mathematical pedagogical practice.

This paper reports the findings from a qualitative study that investigated the beliefs of Australian, primary school in-service teachers (ISTs) and pre-service teachers (PSTs) concerning the integration of children's literature in their mathematics teaching. This study is part of an international study that examined the same beliefs as espoused by both ISTs and PSTs in different countries, e.g., Ireland (Prendergast et al., 2019) and Malta (Farrugia \& Trakulphadetkrai, 2020). Investigation into Australian ISTs' and PSTs' beliefs in relation to the use of children's literature to teach mathematics is warranted as educational findings in different countries are not necessarily applicable to the Australian context, and ISTs' experiences and beliefs are not necessarily the same as those held by PSTs. In addition, the study aligns with the aims of the Australian Curriculum: Mathematics (ACARA, 2018), which include the recognition of connections between areas of mathematics and other disciplines, and the appreciation of mathematics as an accessible and enjoyable discipline to study. As previously noted, children's literature can provide opportunities to investigate concepts in contexts that children can personally relate to and can promote creative communication of mathematics, which are also the primary aims of Australia's Mathematics Curriculum.

\section{Literature review}

\section{Children's literature and mathematics}

Story picture books, which are a form of children's literature, offer a rich source of opportunities to develop mathematical concepts, particularly for young children (e.g., Anderson et al., 2005; van den Heuvel-Panhuisen \& van den Boogard, 2008). According to Marston (2014), mathematical story picture books, or story picture books that can be used to enrich mathematics teaching and learning, can be broadly classified as one of the following three types: perceived-books written to entertain with mathematical concepts found unintentionally and incidentally; explicit-books with mathematical concepts explicitly referenced within the text (e.g., counting books); and embedded - books written to entertain with purposefully embedded mathematical ideas.

Integrating mathematical content through taking mathematical concepts and incorporating them into narrative has been shown to be successful in communicating and retaining mathematical knowledge (Moyer, 2000). Other benefits identified in a review of 21

\footnotetext{
1 In this article, where we use the term teachers, we are referring to both in-service teachers (ISTs) and preservice teachers (PSTs).
} 
studies on the effects of using children's literature to teach K-6 mathematics (NCTM, 2018) included: improved mathematics achievement; heightened interest in, and positive attitudes towards, mathematics; increased engagement of children in mathematical discourse; a wider range of meaningful contexts for learning mathematics; deepened conceptual understanding, and increased mathematical confidence. Illustrations found in picture books can also be useful in supporting the visualisation of mathematical concepts and the linking of oral, written and pictorial representations (NCTM, 2018). Moreover, Hassinger-Das et al. (2015) and Purpura et al. (2017) also report on the positive impact of using mathematical stories in aiding children's language development, particularly their vocabulary knowledge. This is crucial as Trakulphadetkrai et al. (2020) found that children's mathematical ability and language ability are closely linked.

It is important to consider that these are potential benefits and, as with any other pedagogical tool, story picture books may be interpreted and implemented in ways which limit their impact. Sometimes teachers might superficially link a story picture book with a topic they are teaching (Russo \& Russo, 2018). Similarly, not all story picture books are appropriate for teaching mathematical concepts and may even lead to children developing misconceptions (Flevares \& Schiff, 2014; Nurnberger-Haag, 2017). There is also no guarantee that mathematical concepts are accurately or appropriately developed (Bintz et al., 2011) or that the teacher can recognise when this is not the case (Muir et al., 2017).

\section{Use of children's literature in mathematics teaching}

Much of the research conducted into the use of children's literature in mathematics classrooms has focused on the implementation of lessons (e.g., Edelman, 2017; Halsey, 2005), impact on student achievement (e.g., Hong, 1996; Kisker et al., 2012), or use in early years classrooms (e.g., An et al., 2019; Casey et al., 2004). Some of these studies have involved PSTs e.g., An et al.'s (2019) study which investigated how PSTs could creatively generate mathematically focused stories for young children. As with other PST-related studies (e.g., Edelman, 2017), the studies and findings were linked with PSTs' knowledge, rather than their beliefs.

While the aforementioned studies espouse the benefits of integrating children's literature with mathematics, this integration has not necessarily been effectively enacted in classrooms (NCTM, 2018). It may be that some teachers are not convinced of the merits in implementing initiatives that they had not previously considered (Predergast \& Treacy, 2018), or are reluctant to adopt new practices, as is often the case with educational change initiatives (Fullan, 2015). Teachers' perceptions of the need to change is an influential factor in the success of any reform or innovation (Fullan, 2015) and change is likely to occur as a result in shifts in teachers' pre-existing knowledge and beliefs (e.g., Guskey, 1985; Thompson, 1992). Studies that examine the influence that teachers' beliefs have on their uptake of using children's literature to teach mathematical concepts may therefore provide insights into why this uptake is not more widespread.

There is a limited body of research that connects teachers' beliefs to the use of children's literature in the teaching of mathematics (e.g., Cotti \& Schiro, 2004; Farrugia \& Trakulphadetkrai, 2020; Prendergast et al., 2019). In Cotti and Schiro's (2004) study, they created a Mathematics and Children's Literature Belief Inventory to facilitate teachers' understanding of their own ideological positions and those of other teachers. The inventory assisted teachers with identifying which one of four ideological orientations (i.e., Scholar Academic, Social Efficiency, Child Study, and Social Reconstruction) primarily influenced 
their approaches to both teaching and learning and the use of children's literature in the mathematics classroom. The study's deductive approach, whereby orientations and beliefs came from a review of literature only, points to a gap in the research field for other studies to consider additional aspects generated through the use of participant data.

Previous studies conducted by the current study's third author (Farrugia \& Trakulphadetkrai, 2020; Prendergast et al., 2019) investigated perceived barriers to, and enablers for, the integration of children's literature in mathematics classrooms in Ireland and Malta. The studies adopted an inductive approach allowing teachers' beliefs concerning the use of children's literature in mathematics teaching and learning to emerge from open-ended survey data. Similar perceived barriers were found across these two studies e.g., resource constraint, time constraint, lack of pedagogical knowledge and confidence, doubts about outcome expectancy and inhibiting social norms. Moreover, similar perceived enablers were also found across the two studies, e.g., perceived pedagogical benefits, enabling social norms, and love of children's literature. Interestingly, the studies' contextual data also revealed that over $90 \%$ and $80 \%$ of teachers in Ireland and Malta, respectively, reported that they had either never used children's literature in their mathematics teaching or had done so infrequently (i.e., 10 mathematics lessons or less a year). This study will seek to determine whether Australian ISTs and PSTs hold similar beliefs and pedagogical approaches to their Irish and Maltese counterparts.

In summary, the reviewed literature points to a general consensus regarding the benefits of using children's literature to teach mathematical concepts. Despite these identified benefits, there remains limited uptake by teachers in the widespread adoption of children's literature as a mathematical pedagogical approach. It is hypothesised that this limited adoption is likely due to a variety of factors, including the beliefs held by teachers of the value of such an approach. This study aims to investigate teachers' perceived barriers to, and enablers for, the integration of children's literature in mathematics teaching. Through identifying these factors, we will be better placed to direct resources and professional learning into overcoming barriers to implementation of the approach, which has been shown to be beneficial for learning mathematical concepts and developing positive mathematical dispositions (Marston, 2014).

\section{Theoretical framework}

Teachers have a knowledge base for teaching, such as knowledge of content, pedagogical knowledge and knowledge of learners (Shulman, 1987). A teacher's foundation knowledge includes knowledge of their own mathematical knowledge (content) and knowledge of pedagogical approaches and their beliefs (Rowland et al., 2009). A teacher's beliefs influence how they teach mathematics (Thompson, 1992) and can include beliefs related to why and how mathematics is learnt (Rowland et al., 2009). These beliefs about mathematics influence their teaching (Thompson, 1984) and include their planned behaviour and practices for integrating children's literature in mathematics teaching and learning. Others agree that different factors can influence improvement in approaches to teaching mathematics including teachers' interests, beliefs, emotions, knowledge and practice as well as other stakeholder's interest (Kieran et al., 2013).

To allow us to better understand teachers' beliefs, the current study adopted Ajzen's (1991) Theory of Planned Behaviour (TPB) as its underpinning theory. TPB was developed to predict and understand behaviour including perceived barriers and enablers regarding 
someone's beliefs. The following three factors can be used to predict a person's behaviour that is either an enabler of, or barrier to, change. Firstly, Attitude toward the behaviour is a personal evaluation of the behaviour in question and this can be favourable or unfavourable (Ajzen, 2020). In the context of this study, teachers may or may not believe that story picture books can assist children's engagement with their mathematical learning. Secondly, Perceived behavioural control is when a person's beliefs are influenced by factors, such as time, money, assistance from other people that either assist or hinder behaviour (Ajzen, 2020). Finally, Subjective norm is when a person's beliefs are influenced by perceived pressure to perform or not to perform a behaviour (Ajzen, 1991). In any given school, the principal or parents may influence a teacher's beliefs because they approve or disapprove of a behaviour (Ajzen, 2020).

\section{The current study}

Drawing from the research gaps identified, the study aims to analyse and report on Australian ISTs' and PSTs' perceived barriers to and enablers for the integration of children's literature in mathematics teaching. The purpose of our study will be to inform and guide the knowledge of teacher educators and teacher training agencies. In summary, the study set out to address the following specific research question: What do ISTs and PSTs in Australia perceive to be key barriers to, and enablers for, the integration of children's literature in mathematics teaching and learning?

\section{Methods}

\section{Sample}

Using convenience sampling, Authors 1, 2 and 4 invited PSTs from three large universities in Victoria, Queensland and Tasmania to complete the survey. The survey link was provided via an announcement on the university Learning Management System (LMS). Using snowball sampling, ISTs were invited to complete the survey either via social media or via e-mailing primary school teachers that were acquaintances. ISTs were also encouraged to invite other colleagues to complete the survey. This approach ensured a wide-ranging demographic of teachers Australia-wide. This sampling strategy, however, means that it is impossible to indicate a specific response rate. In total, 176 survey participants responded, consisting of 94 ISTs and 82 PSTs.

\section{Characteristics of the survey participants}

As Table 1 illustrates, there were significantly more female than male teachers within each cohort, a common trend in the primary school sector in Australia where females comprise more than $80 \%$ of teaching staff in primary schools (Australian Bureau of Statistics, 2020). Teachers from across all eight states and territories completed the survey. ISTs of the different age groups (4-12 years old) were well represented with a slightly higher number of ISTs teaching Year 2 or Year 3 classes (6-8 years old children). Around $65 \%$ of the ISTs in the study indicated that they had 20 years of teaching experience or less. 
Table 1 Demographic characteristics of the survey participants $(N=176)$

\begin{tabular}{|c|c|c|c|}
\hline & $\begin{array}{l}\text { Total } \\
(N=176)\end{array}$ & $\begin{array}{l}\text { In-service teachers } \\
\text { (ISTs) } \\
(N=94)\end{array}$ & $\begin{array}{l}\text { Pre-service teachers } \\
\text { (PSTs) } \\
(N=82)\end{array}$ \\
\hline Characteristics & $\mathrm{n}(\%)$ & $\mathrm{n}(\%)$ & $\mathrm{n}(\%)$ \\
\hline \multicolumn{4}{|l|}{ Sex } \\
\hline Male & $30(17 \%)$ & $15(16 \%)$ & $15(18.3 \%)$ \\
\hline Female & $146(83 \%)$ & $79(84 \%)$ & $67(81.7 \%)$ \\
\hline \multicolumn{4}{|l|}{ Location } \\
\hline New South Wales & $11(6.3 \%)$ & $11(11.7 \%)$ & $0(0 \%)$ \\
\hline Queensland & $37(21 \%)$ & $5(5.3 \%)$ & $32(39 \%)$ \\
\hline Tasmania & $10(5.7 \%)$ & $4(4.3 \%)$ & $6(7.3 \%)$ \\
\hline Victoria & $109(62 \%)$ & $67(71.3 \%)$ & $42(51.2 \%)$ \\
\hline $\begin{array}{l}\text { Others (i.e. Australian Capital Territory, Northern } \\
\text { Territory, South Australia and Western Aus- } \\
\text { tralia) }\end{array}$ & $9(5.1 \%)$ & $7(7.4 \%)$ & $2(2.4 \%)$ \\
\hline \multicolumn{4}{|l|}{ Class taught } \\
\hline Foundation-Year 1 (4-6 years old) & $25(14.2 \%)$ & $12(12.8 \%)$ & $13(15.9 \%)$ \\
\hline Year 2-Year 3 (6-8 years old) & $47(26.7 \%)$ & $26(27.7 \%)$ & $21(25.6 \%)$ \\
\hline Year 4-Year 5 (8-10 years old) & $33(18.8 \%)$ & $21(22.3 \%)$ & $12(14.6 \%)$ \\
\hline Year 6-Year 7 (10-12 years old) & $38(21.6 \%)$ & $17(18.1 \%)$ & $21(25.6 \%)$ \\
\hline A wide range of class levels & $27(15.3 \%)$ & $16(17 \%)$ & $11(13.4 \%)$ \\
\hline Not indicated & $6(3.4 \%)$ & $2(2.1 \%)$ & $4(4.9 \%)$ \\
\hline \multicolumn{4}{|l|}{ Teaching experience level (years) } \\
\hline $1-10$ & $\mathrm{n} / \mathrm{a}$ & $31(33)$ & $\mathrm{n} / \mathrm{a}$ \\
\hline $11-20$ & $\mathrm{n} / \mathrm{a}$ & $30(32)$ & $\mathrm{n} / \mathrm{a}$ \\
\hline $21-30$ & $\mathrm{n} / \mathrm{a}$ & $16(17)$ & $\mathrm{n} / \mathrm{a}$ \\
\hline$>30$ & $\mathrm{n} / \mathrm{a}$ & $17(18)$ & $\mathrm{n} / \mathrm{a}$ \\
\hline \multicolumn{4}{|c|}{$\begin{array}{l}\text { Whether training on using children's literature in mathematics teaching is/was provided as part of } \\
\text { teacher training }\end{array}$} \\
\hline Yes & $72(41 \%)$ & $28(29.8 \%)$ & $44(53.7 \%)$ \\
\hline No & $89(50.6 \%)$ & $51(54.3 \%)$ & $38(46.3 \%)$ \\
\hline Cannot remember-too long ago & $15(8.5 \%)$ & $15(16 \%)$ & $\mathrm{n} / \mathrm{a}$ \\
\hline \multicolumn{4}{|c|}{ Frequency of using children's literature in mathematics teaching within the current academic year } \\
\hline Never & $67(38.1 \%)$ & $17(18.1 \%)$ & $50(61 \%)$ \\
\hline Infrequently (1-10 lessons) & $65(37 \%)$ & $41(43.6 \%)$ & $24(29.3 \%)$ \\
\hline Frequently (> 10 lessons) & $32(18.2 \%)$ & $30(31.9 \%)$ & $2(2.4 \%)$ \\
\hline Not indicated & $12(6.8 \%)$ & $6(6.4 \%)$ & $6(7.3 \%)$ \\
\hline
\end{tabular}

When ISTs were asked how frequently they had incorporated children's literature as part of their mathematics teaching in the current academic year, nearly $80 \%$ responded that they had either never used children's literature in their mathematics teaching or had used but infrequently (i.e. 10 mathematics lessons or less per school year). Only 30\% of ISTs and $2.4 \%$ of PSTs reported that they have used children's literature frequently in their mathematics teaching (i.e. $10+$ lessons). Concerning the latter, it is perhaps to be expected as they have had far fewer opportunities to do so than ISTs. When asked whether they had 
received any training on using children's literature in mathematics teaching as part of their teacher training education, around a third of ISTs (29.8\%) reported that they had receiving training, whereas more than half of the PSTs (53.7\%) reported that such training was provided.

\section{Data collection}

The data were collected via an online open-ended survey. The survey contained four key sections: the first section asked the participants to define and give examples of children's literature; the second section asked the participants to write the first five thoughts that come to mind when they think about 'the integration of children's literature in mathematics teaching and learning'; the third section contained eight questions relating to their experience (if any) of integrating children's literature; and the fourth and final section asked contextual information about the participants (see Table 1). This survey was developed and piloted by Trakulphadetkrai (2015) with the English sample and subsequently developed further with the Irish sample (Prendergast et al., 2019) and the Maltese sample (Farrugia \& Trakulphadetkrai, 2020).

The data reported in this paper were drawn from the participants' responses to the following two questions in the third section of the survey: (1) 'In your experience, what are the key barriers that stop you from incorporating (more) children's literature in your mathematics teaching?' and (2) 'If you have previously incorporated children's literature in your mathematics teaching, what enabled / encouraged you to do so?'.

All three authors in Australia obtained ethical approval from their respective institutions to conduct the research.

\section{Data analysis}

During the data preparation stage, any written responses that were vague, ambiguous, or not specifically relevant to either perceived barriers or enablers were discarded (e.g., "Many children have demonstrated their interests towards mathematics as basic mathematics knowledge and skills are embedded in most early childhood centre's curriculum.").

The open-ended survey data were then analysed thematically and inductively using the constant comparative method (Lincoln \& Cuba, 1985). Specifically, the focus was first on identifying "categories", so that similar categories could then be grouped together into a set of coherent themes. For example, these three categories - Limited or lack of awareness of suitable children's literature for specific mathematical concepts or age groups; Limited or lack of awareness / knowledge / experience / training in the approach, and Perceived difficulty and/or fear in implementing the approach-were later grouped together under a theme, labelled Lack of Pedagogical Knowledge and Confidence. To capture how often each of these categories was mentioned by the survey respondents, descriptive statistics were used. Survey respondents were able to state more than one perceived barrier and enabler, but any beliefs repeated by the same respondents were not counted twice.

Each category itself was made up of teachers' responses relevant to that particular category. For example, the Limited or lack of awareness/knowledge/experience/training in the approach category was made up of teachers' responses, such as "I do not have the specific understanding of how to effectively and seamlessly integrate children's literature into my maths teaching" and "Lack of understanding of how to integrate it". This stage of analysis was achieved through several rounds of reading and re-reading the responses. It is also 
worth noting that, in a few cases, more than one category could be found in single sentences. For example, an IST wrote: "Too much on the timetable to consider and did not have the time to search for literature that matched the topics." Through the process of moderation, it was agreed that the first part of the sentence would be coded as the Curriculum pressure category and the second part of the sentence would be coded as the Limited or lack of time to search for suitable children's literature category. In brief, the unit of analysis was thus not necessarily always at the sentence level, and could be made up of a cluster of words within a sentence.

To ensure the coding reliability, the main coder (Author 3) coded all the data and his coding was then moderated by the other three authors - each of whom moderated a third of the entire dataset. Due to the nature of the data being open-ended and non-binary, instead of the Cohen's kappa coefficient, the inter-coder agreement percentage was calculated. The inter-coder agreement percentages for the perceived barriers and enablers were relatively high (90.2\% and $86.1 \%$ respectively), highlighting that the coding frameworks that we have developed for this study's analysis were reliable. That said, we fully acknowledge that the key drawback of reporting inter-coder agreement percentages is how agreement that could have happened by chance was not taken into account, so those interpreting our reported inter-coder agreement percentages should bear this in mind. Any disagreements in coding were subsequently discussed until coding agreement was reached.

\section{Results}

\section{Perceived barriers}

In total, 169 of the 176 teachers responded to the following survey question: 'In your experience, what are the key barriers that stop you from incorporating (more) children's literature in your mathematics teaching?' These included teachers who reported having never incorporated children's literature in their mathematics teaching and those who have had some experience. Of these 169 teachers, 90 were ISTs and 79 were PSTs. As each respondent was allowed to state more than one perceived barrier, the total number of coding occurrences on perceived barriers $(N=200)$ is higher than the number of survey respondents $(N=169)$. These 200 coding occurrences excluded the 12 coding occurrences that the coders identified as No perceived barriers (e.g., "None").

From the thematic coding analysis, 13 perceived barriers were identified and grouped under five themes, namely Lack of Pedagogical Knowledge and Confidence, Time Constraint, Resource Constraint, Inhibiting Social Norms and Doubts about Outcome Expectancy (see Table 2).

Theme 1, Lack of Pedagogical Knowledge and Confidence, is made up of three categories and they collectively account for almost half (48.5\%) of all the coding occurrences on perceived barriers, making it the most predominant cluster of perceived barriers for the teachers in this study. The first of these categories, Limited or lack of awareness of suitable children's literature for specific mathematical concepts or age groups, alone accounts for almost a third of all coding occurrences (31.5\%). This is followed by Limited or lack of awareness / knowledge / experience / training in the approach (15.5\%) and Perceived difficulty and/or fear in implementing the approach (1.5\%). Overall, this first theme orients us towards the importance of training as one possible source for the knowledge these teachers believed to be lacking. 
Table 2 Survey responses concerning perceived barriers to the integration of children's literature in mathematics teaching

\begin{tabular}{|c|c|c|c|c|}
\hline \multirow[t]{2}{*}{ Categories } & \multirow[t]{2}{*}{ Examples of statement } & $\begin{array}{l}\text { Total } \\
(N=169 / 176)\end{array}$ & $\begin{array}{l}\text { In-service } \\
\text { teachers } \\
\text { (ISTs) } \\
(N=90 / 94)\end{array}$ & $\begin{array}{l}\text { Pre-service } \\
\text { teachers } \\
\text { (PSTs) } \\
(N=79 / 82)\end{array}$ \\
\hline & & $\begin{array}{l}f^{*} \\
(\%)\end{array}$ & $\begin{array}{l}f^{*} \\
(\%)\end{array}$ & $\begin{array}{l}f^{*} \\
(\%)\end{array}$ \\
\hline
\end{tabular}

\section{Theme 1: lack of pedagogical knowledge and confidence $(48.5 \%)$}

1 Limited or lack of aware-
ness of suitable children's
literature for specific
mathematical concepts or
age groups
2 Limited or lack of
awareness / knowledge /
experience / training in the
approach
3 Perceived difficulty and/or
fear in implementing the
approach

Theme 2: time constraint (26.5\%)
"Not knowing good examples ferent topics-not having a built-up database."

"I do not have the specific understanding of how to effectively and seamlessly integrate children's literature into my maths teaching."

"Generally fearful of taking a risk with something like mathematics, that must be taught so explicitly." of texts to use for the dif-

63

$(31.5 \%)$

33

(32\%)

30

31

6

(15.5\%) (5.8\%)

3

0

16

4

books with a mathematical connection." dren's literature

5 Limited or lack of time (unspecified)

6 Curriculum pressure

"Limited time."

"So much content to coveroften little time to reinforce concepts in an overarching manner; often little time to give contextual problemsolving opportunities for reinforcing mathematical concepts."

7 Limited or lack of time to plan for lessons using this approach

8 Limited or lack of time to read a story during the lesson

"The time it takes to meaningfully plan lessons or units around the key ideas/ messages in a text can be a limitation."

20

$(15.5 \%)$

14

9

5

(7\%) $\quad(8.7 \%)$

10

3

5

2

$(1.9 \%)$

3

$(2.5 \%)$

"If time was running short in a lesson the stories would be cut out."

4

4

0

$(2 \%)$

$(3.9 \%)$

(0\%)

Theme 3: resource constraint (15\%)

9 Limited or lack of suitable

"I struggle to find books in my school that were available for the topics I was teaching e.g., school two-digit addition and time." 
Table 2 (continued)

\begin{tabular}{|c|c|c|c|c|}
\hline \multirow[t]{2}{*}{ Categories } & Examples of statement & $\begin{array}{l}\text { Total } \\
(N=169 / 176)\end{array}$ & $\begin{array}{l}\text { In-service } \\
\text { teachers } \\
\text { (ISTs) } \\
(N=90 / 94)\end{array}$ & $\begin{array}{l}\text { Pre-service } \\
\text { teachers } \\
(\mathrm{PSTs}) \\
(N=79 / 82)\end{array}$ \\
\hline & & $\begin{array}{l}f^{*} \\
(\%)\end{array}$ & $\begin{array}{l}f^{*} \\
(\%)\end{array}$ & $\begin{array}{l}f^{*} \\
(\%)\end{array}$ \\
\hline
\end{tabular}

\section{Theme 4: inhibiting social norms (6\%)}

\begin{tabular}{|c|c|}
\hline $\begin{array}{l}10 \text { Perceived unwillingness } \\
\text { of key stakeholders (e.g., } \\
\text { school leaders, mentors, } \\
\text { parents) for this approach } \\
\text { to be trialled }\end{array}$ & $\begin{array}{l}\text { "In my own classroom, I would } \\
\text { feel very comfortable incor- } \\
\text { porating children's literature } \\
\text { in my Maths teaching. I find } \\
\text { being out on Prac [teaching } \\
\text { placement] though is very } \\
\text { limiting if the teacher [men- } \\
\text { tor] isn't willing and open } \\
\text { to change and trial in the } \\
\text { classroom. Totally inflexible } \\
\text { teacher not willing to allow } \\
\text { me to try anything outside } \\
\text { her teaching repertoire." }\end{array}$ \\
\hline
\end{tabular}

Theme 5: doubts about outcome expectancy (4\%)

\begin{tabular}{|c|c|c|c|c|}
\hline $\begin{array}{l}11 \text { Perceived unsuitability of } \\
\text { the approach for children } \\
\text { of certain age groups }\end{array}$ & $\begin{array}{l}\text { "I am unsure if this strategy } \\
\text { would be as appropriate for } \\
\text { upper primary as it is for } \\
\text { lower primary." }\end{array}$ & $\begin{array}{l}3 \\
(1.5 \%)\end{array}$ & $\begin{array}{l}0 \\
(0 \%)\end{array}$ & $\begin{array}{l}3 \\
(3.1 \%)\end{array}$ \\
\hline $\begin{array}{l}12 \text { Perceived limitation of } \\
\text { the approach in catering for } \\
\text { different learning needs }\end{array}$ & $\begin{array}{l}\text { "Some young children strug- } \\
\text { gle significantly with }[\ldots] \\
\text { reading." }\end{array}$ & $\begin{array}{l}3 \\
(1.5 \%)\end{array}$ & $\begin{array}{l}2 \\
(1.9 \%)\end{array}$ & $\begin{array}{l}1 \\
(1 \%)\end{array}$ \\
\hline \multirow[t]{2}{*}{$\begin{array}{l}13 \text { Perceived incompat- } \\
\text { ibility between children's } \\
\text { literature and mathematics } \\
\text { teaching }\end{array}$} & $\begin{array}{l}\text { "Teaching can be a bit 'siloed'. } \\
\text { At times when teaching } \\
\text { using a book I felt a bit torn } \\
\text { when students would pick } \\
\text { up something they were } \\
\text { interested in [...] but I had } \\
\text { prepared a lesson on estimat- } \\
\text { ing and counting plastic toys } \\
\text { in a big jar." }\end{array}$ & $\begin{array}{l}2 \\
(1 \%)\end{array}$ & $\begin{array}{l}2 \\
(1.9 \%)\end{array}$ & $\begin{array}{l}0 \\
(0 \%)\end{array}$ \\
\hline & Total (f) & 200 & 103 & 97 \\
\hline
\end{tabular}

The bolden numbers are essentially the sums

$*_{f}$ is here taken to refer to the number of teachers who mentioned a particular belief. Beliefs repeated by the same teacher were not counted twice. Participants were able to state more than one perceived barrier, explaining why the total number of $f(200)$ exceeded the total number of teachers who responded to this survey question (169) 
The second most predominant theme is Time Constraint which accounts for nearly a third of all coding occurrences on perceived barriers (26.5\%). The theme is made up of five categories: Limited or lack of time to search for suitable children's literature (10\%); Curriculum pressure (5\%) which is concerned with the belief that the overcrowded mathematics curriculum somehow means teachers cannot afford to spend time teaching mathematics using children's literature; Limited or lack of time to plan for lessons using this approach (2.5\%), and Limited or lack of time to read a story during the lesson (2\%). Moreover, a number of teachers also indicated limited or lack of time as a barrier but did not specify the impact of that lack of time. Instead of disregarding these responses as ambiguous, a decision was made as part of the moderation process to retain them under the Limited or lack of time (unspecified) category ( $7 \%$ ).

Theme 3, Resource Constraint (15\%) is made up of only one category, Limited or lack of suitable children's literature at school. Even if teachers were aware of the wide range of children's literature that could be used for mathematics teaching, it would not mean much if their schools' library do not have such books and/or they cannot access the stories online.

Theme 4, Inhibiting Social Norms, accounts for $6 \%$ of all the coding occurrences on perceived barriers and its presence provides a useful contrast to Enabling Social Norms, one of the Perceived Enablers themes to be discussed in the following section. The one category that makes up this theme is Perceived unwillingness of key stakeholders for this approach to be trialled where teachers believed that their attempt to incorporate children's literature in their mathematics teaching would not be received positively by, for example, their principal, teaching colleagues or parents. More PSTs $(9.3 \%)$ cited this perceived barrier as compared to ISTs (2.9\%). Arguably, this highlights the potential power dynamic at play between PSTs and other stakeholders at school during their teaching placement (e.g., their mentors, school leaders, etc.), and how PSTs may be overly concerned by what such stakeholders think about their teaching methods.

The fifth and final theme, Doubts about Outcome Expectancy (4\%), is concerned with teachers' perceptions that question the effectiveness and suitability of the approach. The theme is made up of three types of doubts, i.e. Perceived unsuitability of the approach for children of certain age groups $(1.5 \%)$ where some teachers perceived the use of children's literature in mathematics teaching to be suitable for only very young children; Perceived limitation of the approach in catering for different learning needs (1.5\%) where some teachers cited how the use of children's literature in mathematics teaching could be problematic for some children, for example, those with language difficulties; and Perceived incompatibility between children's literature and mathematics teaching (1\%) where some teachers believed in the separation of mathematics and literacy as two separate subjects.

The three most-cited categories combined account for over $60 \%$ of all the coding on perceived barriers, and these categories are: Limited or lack of awareness of suitable children's literature for specific mathematical concepts or age groups (31.5\%); Limited or lack of awareness/knowledge/experience/training in the approach (15.5\%); and Limited or lack of suitable children's literature at school (15\%). Approaches that can address each of these key perceived barriers as part of teacher training will be discussed in the Discussion section.

When examining the differences between ISTs' and PSTs' responses, a higher proportion of ISTs $(22.3 \%)$ cited the Limited or lack of suitable children's literature at school category as a key barrier when compared with PSTs (7.2\%). The opposite was true for the Limited or lack of awareness / knowledge / experience / training in the approach category where more PSTs $(25.8 \%)$ proportionally cited this barrier when compared with ISTs (5.8\%). Finally, ISTs appeared to be more sensitive to time constraints citing Limited or 
lack of time to search for suitable children's literature (22.3\%) as a key barrier when compared with PSTs (7.2\%).

\section{Perceived enablers}

In total, 118 of the 176 teachers responded to the following survey question: 'If you have previously incorporated children's literature in your mathematics teaching, what enabled / encouraged you to do so?'. Of these 118 teachers, 81 were ISTs and 37 were PSTs. The substantial drop in PSTs' response to this question could be attributed to their limited teaching opportunities in classrooms. Again, as each teacher was allowed to state more than one perceived enabler, the total number of coding occurrences on perceived enablers $(N=155)$ is higher than the number of survey respondents $(N=118)$.

From the thematic coding analysis, 14 perceived enablers were identified and grouped into six themes, namely Perceived Pedagogical Benefits, Love of Stories, Desire to Improve Teaching, Knowledge of the Approach, Enabling Social Norms, and Availability of Resources (see Table 3).

The first theme, Perceived Pedagogical Benefits, is made up of six categories, and they collectively accounted for $57.4 \%$ of all coding on perceived enablers, making it the most predominant cluster of perceived enablers for the teachers in this study. To avoid any unnecessary repetition here, these six categories can be found in Table 3. Of particular importance are the first two categories which collectively account for nearly $50 \%$ of all the coding on perceived enablers: Encouraged and inspired by teacher's own perception that teaching mathematics through children's literature makes the teaching more engaging and fun $(31 \%)$ and Encouraged and inspired by teacher's own perception that teaching mathematics through children's literature helps children to apply and make meaningful connections between their mathematics learning and their everyday life (14.8\%).

Feeling encouraged and inspired by both teachers' and children's love of stories makes up the second theme, Love of Stories, which accounts for $11.7 \%$ of all coding occurrences on perceived enablers.

Theme 3, Desire to Improve Teaching, is made up of two categories: Encouraged and inspired by teacher's own belief in the value of cross-curricular teaching (9\%) and Encouraged and inspired by teacher's own desire to try new methods of teaching mathematics (1.9\%). This theme is concerned with teachers whose main desire is to seek ways to help them improve their mathematics teaching and, if using children's literature could help them achieve that goal, then they would choose this approach.

Accounting for $9.6 \%$ of all coding occurrences on perceived enablers, Theme 4, Knowledge of the Approach, is also made up of two categories: Encouraged and inspired by training from lecturer at college and other forms of professional development training $(7.7 \%)$ and Encouraged and inspired by teacher's own awareness of children's literature that are appropriate for mathematics teaching (1.9\%). This theme is concerned with teachers who would use children's literature in their mathematics teaching if they knew how, highlighting the importance of training, both professional learning and initial teacher education, for ISTs and PSTs, respectively.

Theme 5, Enabling Social Norms, accounts for $7.1 \%$ of all the coding on perceived enablers, and is made up of one category Encouraged and inspired by key stakeholders. In the context of this theme, teachers would be encouraged to teach mathematics using children's literature if encouragement to use such resources was given by their school leaders, 
Table 3 Survey responses concerning perceived enablers for the integration of children's literature in mathematics teaching

\begin{tabular}{|c|c|c|c|c|}
\hline Categories & Examples of statement & $\begin{array}{l}\text { Total } \\
(N=118 / 176)\end{array}$ & $\begin{array}{l}\text { In-service } \\
\text { teachers } \\
(\text { ISTs }) \\
(N=81 / 94)\end{array}$ & $\begin{array}{l}\text { Pre-service } \\
\text { teachers } \\
\text { (PSTs) } \\
(N=37 / 82)\end{array}$ \\
\hline & & $\begin{array}{l}f^{*} \\
(\%)\end{array}$ & $\begin{array}{l}f^{*} \\
(\%)\end{array}$ & $\begin{array}{l}f^{*} \\
(\%)\end{array}$ \\
\hline \multicolumn{5}{|c|}{ Theme 1: perceived pedagogical benefits $(57.4 \%)$} \\
\hline $\begin{array}{l}1 \text { Encouraged and inspired by } \\
\text { teacher's own perception that } \\
\text { teaching mathematics through } \\
\text { children's literature makes } \\
\text { the teaching more engaging } \\
\text { and fun }\end{array}$ & $\begin{array}{l}\text { "I like to try and make my } \\
\text { mathematics lessons as } \\
\text { exciting and engaging as } \\
\text { possible and I find that } \\
\text { incorporating picture books } \\
\text { is a great way of achieving } \\
\text { this." }\end{array}$ & $\begin{array}{l}48 \\
(31 \%)\end{array}$ & $\begin{array}{l}36 \\
(32.4 \%)\end{array}$ & $\begin{array}{l}12 \\
(27.3 \%)\end{array}$ \\
\hline $\begin{array}{l}2 \text { Encouraged and inspired by } \\
\text { teacher's own perception that } \\
\text { teaching mathematics through } \\
\text { children's literature helps chil- } \\
\text { dren to apply and make mean- } \\
\text { ingful connections between } \\
\text { their mathematics learning and } \\
\text { their everyday life }\end{array}$ & $\begin{array}{l}\text { "A belief in the power of chil- } \\
\text { dren's literature to provide } \\
\text { a meaningful and engaging } \\
\text { context for mathematical } \\
\text { problem solving." }\end{array}$ & $\begin{array}{l}23 \\
(14.8 \%)\end{array}$ & $\begin{array}{l}16 \\
(14.4 \%)\end{array}$ & $\begin{array}{l}7 \\
(15.9 \%)\end{array}$ \\
\hline $\begin{array}{l}3 \text { Encouraged and inspired by } \\
\text { teacher's own perception that } \\
\text { teaching mathematics through } \\
\text { children's literature makes } \\
\text { mathematics learning more } \\
\text { accessible to students }\end{array}$ & $\begin{array}{l}\text { "It would have helped me as } \\
\text { a child when I found maths } \\
\text { too abstract and needed } \\
\text { scaffolding support to make } \\
\text { the bridge." }\end{array}$ & $\begin{array}{l}9 \\
(5.8 \%)\end{array}$ & $\begin{array}{l}7 \\
(6.3 \%)\end{array}$ & $\begin{array}{l}2 \\
(4.5 \%)\end{array}$ \\
\hline $\begin{array}{l}4 \text { Encouraged and inspired by } \\
\text { teacher's own perception that } \\
\text { teaching mathematics through } \\
\text { children's literature also helps } \\
\text { with children's language } \\
\text { development }\end{array}$ & $\begin{array}{l}\text { "Because it allows students } \\
\text { to think mathematically and } \\
\text { enhance their literacy skills } \\
\text { at the same time." }\end{array}$ & $\begin{array}{l}4 \\
(2.6 \%)\end{array}$ & $\begin{array}{l}3 \\
(2.7 \%)\end{array}$ & $\begin{array}{l}1 \\
(2.3 \%)\end{array}$ \\
\hline $\begin{array}{l}5 \text { Encouraged and inspired by } \\
\text { teacher's own perception that } \\
\text { teaching mathematics through } \\
\text { children's literature helps chil- } \\
\text { dren to visualise mathematical } \\
\text { concepts }\end{array}$ & $\begin{array}{l}\text { "To support students to visu- } \\
\text { ally connect with concept." }\end{array}$ & $\begin{array}{l}3 \\
(1.9 \%)\end{array}$ & $\begin{array}{l}3 \\
(2.7 \%)\end{array}$ & $\begin{array}{l}0 \\
(0 \%)\end{array}$ \\
\hline $\begin{array}{l}6 \text { Encouraged and inspired by } \\
\text { teacher's own perception that } \\
\text { teaching mathematics through } \\
\text { children's literature is an effec- } \\
\text { tive way to teach mathematics }\end{array}$ & $\begin{array}{l}\text { "Been doing it for a long time } \\
\text { and know it's effective." }\end{array}$ & $\begin{array}{l}2 \\
(1.3 \%)\end{array}$ & $\begin{array}{l}2 \\
(1.8 \%)\end{array}$ & $\begin{array}{l}0 \\
(0 \%)\end{array}$ \\
\hline \multicolumn{5}{|l|}{ Theme 2: love of stories $(11.7 \%)$} \\
\hline $\begin{array}{l}7 \text { Encouraged and inspired by } \\
\text { teacher's love of stories }\end{array}$ & $\begin{array}{l}\text { "I love picture story books } \\
\text { so it's natural for me to use } \\
\text { them." }\end{array}$ & $\begin{array}{l}10 \\
(6.5 \%)\end{array}$ & $\begin{array}{l}8 \\
(7.2 \%)\end{array}$ & $\begin{array}{l}2 \\
(4.5 \%)\end{array}$ \\
\hline $\begin{array}{l}8 \text { Encouraged and inspired by } \\
\text { children's love of stories }\end{array}$ & $\begin{array}{l}\text { "Students, in my experience, } \\
\text { love stories being read to } \\
\text { them and therefore really get } \\
\text { involved in the learning." }\end{array}$ & $\begin{array}{l}8 \\
(5.2 \%)\end{array}$ & $\begin{array}{l}4 \\
(3.6 \%)\end{array}$ & $\begin{array}{l}4 \\
(9.1 \%)\end{array}$ \\
\hline
\end{tabular}


Table 3 (continued)

\begin{tabular}{llll}
\hline Categories & Examples of statement & $\begin{array}{l}\text { Total } \\
(N=118 / 176)\end{array}$ & $\begin{array}{l}\text { In-service } \\
\text { teachers } \\
\text { (ISTs) }\end{array}$ \\
& & $\begin{array}{l}\text { Pre-service } \\
\text { teachers } \\
\text { (PSTs) }\end{array}$ \\
& & $(N=81 / 94) \quad(N=37 / 82)$
\end{tabular}

\section{Theme 3: desire to improve teaching (10.9\%)}

$\begin{array}{lllll}\begin{array}{l}\text { Encouraged and inspired by } \\ \text { teacher's own belief in the } \\ \text { value of cross-curricular } \\ \text { teaching }\end{array} & \begin{array}{l}\text { "I thought it was important } \\ \text { to encourage literacy in } \\ \text { the maths and integrate the } \\ \text { subjects." }\end{array} & \begin{array}{l}14 \\ (9 \%)\end{array} & (9 \%) & \begin{array}{l}\text { (9.1\%) } \\ \text { 10 Encouraged and inspired } \\ \text { by teacher's own desire to }\end{array} \\ \begin{array}{l}\text { "Trying to find new ways to } \\ \text { teach concepts." }\end{array} & 3 & 3 & 0 \\ \end{array}$
try new methods of teaching mathematics

\section{Theme 4: knowledge of the approach $(9.6 \%)$}

11 Encouraged and inspired by
training from lecturer at col-
lege and other forms of profes-
sional development training
12 Encouraged and inspired by
teacher's own awareness of
children's literature that are
appropriate for mathematics
teaching
"I went to a Professional Learning [...] that gave some great examples of what literature we could use in our maths lessons."

"Knew of the text and how it linked to the concept."

$\begin{array}{lll}12 & 6 & 6 \\ (7.7 \%) & (5.4 \%) & (13.6 \%) \\ & & \\ 3 & 2 & 1 \\ (1.9 \%) & (1.8 \%) & (2.3 \%)\end{array}$

\section{Theme 5: enabling social norms (7.1\%)}
13 Encouraged and inspired by key stakeholders (e.g., school leaders, mentors, colleagues and parents)

"Mentor teacher encourage to
do so as students tend to me
more captivated by stories."

$\begin{array}{lll}11 & 7 & 4 \\ (7.1 \%) & (6.3 \%) & (9.1 \%)\end{array}$

\section{Theme 6: availability of resources (3.2\%)}

\begin{tabular}{|c|c|c|c|c|}
\hline \multirow[t]{2}{*}{$\begin{array}{l}14 \text { Encouraged and inspired by } \\
\text { available resources }\end{array}$} & $\begin{array}{l}\text { "We have a well stocked } \\
\text { library with accompanying } \\
\text { ideas ready to use for your } \\
\text { maths lessons." }\end{array}$ & $\begin{array}{l}5 \\
(3.2 \%)\end{array}$ & $\begin{array}{l}4 \\
(3.6 \%)\end{array}$ & $\begin{array}{l}1 \\
(2.3 \%)\end{array}$ \\
\hline & Total (f) & 155 & 111 & 44 \\
\hline
\end{tabular}

The bolden numbers are essentially the sums

$*_{f}$ is here taken to refer to the number of teachers who mentioned a particular belief. Beliefs repeated by the same teacher were not counted twice. Participants were able to state more than one perceived enabler, explaining why the total number of $f(155)$ exceeded the total number of teachers who responded to this survey question (118)

mentors, colleagues and/or parents. As previously noted, this theme is a welcome contrast to the Inhibiting Social Norms theme found earlier in the Perceived Barriers section.

The sixth and final theme, Availability of Resources, accounts for $3.2 \%$ of all coding occurrences on perceived enablers and is made up of one category Encouraged and inspired by available resources. Specifically, teachers would be encouraged to teach mathematics using children's literature if their school's library is stocked with suitable children's literature for mathematics teaching or if these materials are available online. In addition, teachers are much more likely to use stories recommended by their peers.

The three most-cited Perceived Enablers account for over half $(53.5 \%)$ of all coding occurrences on perceived enablers, and these categories are: Encouraged and inspired by 
teacher's own perception that teaching mathematics through children's literature makes the teaching more engaging and fun (31\%); Encouraged and inspired by teacher's own perception that teaching mathematics through children's literature helps children to apply and make meaningful connections between their mathematics learning and their everyday life (14.8\%); and Encouraged and inspired by training from lecturer at university and other forms of professional development training (7.7\%).

Proportionally, almost all perceived enablers were cited equally by both ISTs and PSTs. An exception is the Encouraged and inspired by training from lecturer at college and other forms of professional development training category where noticeably more PSTs $(13.6 \%)$ cited this enabler compared to ISTs (5.4\%).

\section{Discussion}

Our study set out to investigate Australian ISTs' and PSTs' perceived barriers to, and enablers for, the integration of children's literature in mathematics teaching and learning. The key findings from our survey data, as framed by Ajzen's (1991) Theory of Planned Behaviour (TPB), will now be discussed.

\section{Perceived barriers}

\section{Perceived behavioural control}

Our discussion of the three most-cited themes of perceived barriers (i.e., Lack of Pedagogical Knowledge and Confidence, Time Constraint and Resource Constraint) is framed using the Perceived behavioural control component of Ajzen's (1991) TPB as they are all related to factors that could hinder a particular behaviour.

Concerning the lack of pedagogical knowledge and confidence (Theme 1), this includes a lack of awareness of suitable children's literature for teaching mathematical concepts for both cohorts. As part of teacher training, both ISTs and PSTs could be made aware of the over 400 story picture books in English language that can be used to teach over 40 mathematical concepts as collated on the MathsThroughStories.org website. While training can certainly make ISTs and PSTs aware of resources that are available, there is no guarantee that the resources will be implemented using appropriate pedagogical approaches. Ongoing training and strategies, e.g., setting up communities of practice that provide a forum for ongoing sharing of ideas, would assist with teachers having ongoing access to resources that would extend their knowledge base. In addition, one fourth of the PSTs reported having limited or no knowledge of the approach when using story picture books, which could be seen as surprising given PSTs' currency of their training. However, the 25\% reported might be less about awareness and training and more about a lack of mathematics teaching experience with story picture books. Further professional development experiences could help to influence their beliefs regarding the meaningful connections to mathematics teaching and learning provided by quality story picture books, including tasks that encourage engagement, problem solving and reasoning (e.g., Muir et al., 2017). The $30 \%$ of ISTs who regularly use story picture books and as part of a community of practice, could be encouraged at a local level to assist with changing other teachers' praxis and beliefs concerning teaching mathematics with story picture books. 
The majority of teachers in the study also reported time constraints (Theme 2) as being a key barrier to integrating children's literature in their mathematics teaching. Within this theme, limited or lack of time to search for suitable children's literature was cited frequently, particularly by ISTs. It is thus crucial that they are introduced and encouraged to use on-line databases of recommendations for mathematical story picture books (categorised according to mathematical concepts) like the example given in the previous paragraph, so that their perceived barrier can be addressed. The finding that more ISTs $(22.3 \%)$ cited this perceived barrier when compared with PSTs (7.2\%) could be that ISTs have much less time to search for relevant teaching resources in general when compared with PSTs who may have to find relevant teaching resources as part of their mandatory coursework.

A number of teachers also cited curriculum pressure as being another perceived barrier within Theme 2 . One potential solution which could address this perceived barrier is encouraging these teachers to teach in a cross-curricular manner, using one story picture book to achieve the learning outcomes of both mathematics and literacy, extending children' literacy and vocabulary by discussing the mathematical concepts of the story (NCTM, 2018).

Some teachers reported a resource constraint (Theme 3) and difficulties sourcing story picture books suitable for mathematics teaching and learning due to a perceived or actual lack of resources at school. Professional development could support these teachers by assisting them to utilise story picture books that contain, as Marston (2014) describes, perceived mathematical content, i.e. story picture books that are written mainly to entertain, with the mathematical concepts incidental. They could achieve this goal by reading these books with a 'mathematical lens' (Trakulphadetkrai, 2018), so that they could begin to consider opportunities for making meaningful mathematical connections with their favourite story picture books, without needing to buy story picture books with explicit mathematical focus. Furthermore, professional development opportunities could be targeted around providing teachers with practical resources, such as ready-made tasks linked to story picture books and key mathematical concepts and online stimuli, such as YouTube videos. It is likely that once teachers start utilising such resources, they may be more convinced about the merits of utilising story picture books, thus extending their knowledge and shifting their beliefs regarding the value of such approaches.

\section{Subjective norm}

The fourth theme, Inhibiting Social Norms, aligns with the Subjective norms component of Ajzen's (1991) TPB as it relates to the extent to which teachers felt worried that teaching mathematics using children's literature might be perceived negatively by key stakeholders in their schools (e.g., school leaders, teaching colleagues or parents). As noted, more PSTs cited this perceived barrier (arguably due to the power dynamic between them and their mentors during their teaching placement). One way to address this perceived barrier is for mathematics teacher educators to encourage PSTs to have conversations with their mentors regarding the trialling of different pedagogical approaches by making connection between theory and practice. All teachers should be encouraged to identify themselves as important stakeholders and experts who are willing to trial different approaches to teaching mathematics (Kieran et al., 2013). 


\section{Attitude towards the behaviour}

The final theme, Doubts about Outcome Expectancy, aligns with the Attitude towards the behaviour component of Ajzen's (1991) TPB as it relates to teachers' personal evaluation of the behaviour in question. In this instance, three key perceived barriers emerged that could lead to teachers' unfavourable evaluation of teaching mathematics using children's literature. Specifically, they include perceived unsuitability of the approach for children of certain age groups; perceived limitation of the approach in catering for different learning needs; and perceived incompatibility between children's literature and mathematics teaching. This highlights a need for teachers of older children (e.g., 10+ years old) to recognise that there are many suitable story picture books that can be used as a springboard for teaching more complex mathematical concepts, and for their school's Mathematics Lead to encourage them to use it as part of their teaching. For example, in Heads or Tails (Muir, 2018), children engage with a story related to the probability of an event occurring. After reading the story, children might predict then flip two coins, 20 times, record outcomes, and then compare and discuss predictions and results. Such experiences could demonstrate to teachers with perceived barriers about the potential for story picture books to cater for children with different learning needs. For example, story picture books can be used as a springboard for differentiating the learning through the use of open-ended tasks with enabling and extending prompts (Sullivan et al., 2006). Enabling prompts can be posed to children having difficulty with the main task and extending prompts aim to extend the children's responses to the main task, such as making a generalisation (Sullivan, 2018). There are many other examples of rich, challenging tasks targeted at upper primary-age children developed around narratives that include enabling and extending prompts in an aim to optimise the level of challenge for all children participating in the lesson (e.g., Russo, 2018; Russo \& Russo, 2019). Such lessons also demonstrate teachers' purposeful and meaningful context and connections between literacy and mathematics.

\section{Perceived enablers}

\section{Attitude towards the behaviour}

Our discussion of the three most-cited themes of perceived enablers (i.e. Perceived pedagogical benefits; Love of stories; and Desire to improve teaching) is framed using the Attitude towards the behaviour component of Ajzen's (1991) TPB as it relates to teachers' personal evaluation of the behaviour in question. In this instance, these perceived enablers could arguably lead to teachers' favourable evaluation of using children's literature as part of their mathematics pedagogy. Similarly, if teachers see the value of the approach, they may be more motivated to overcome some of the more practical barriers noted, such as sourcing appropriate books or overcoming time constraints.

In relation to Perceived pedagogical benefits (Theme 1), there were five themes that teachers reported as enablers for the integration of children's literature in mathematics teaching. Specifically, teachers were encouraged and inspired because children's literature is a more engaging way of teaching mathematics and helps make mathematical connections meaningful and accessible to children. It also helps with language development and the visualisation of mathematical concepts. 
The majority of teachers who have used story picture books in their mathematics teaching believe that teaching mathematics is more engaging via the use of such resource. The literature supports this belief reporting that children can be highly motivated when the story provides a hook for mathematical learning. In addition, teachers are engaged because they can choose stories they enjoy and the task or investigation can be engaging for children because it includes a range of mathematical ideas (Russo \& Russo, 2018). Others agree that engagement should be fostered through careful selection of appropriate literature and purposeful mathematical tasks that might also promote problem solving and reasoning (e.g., Muir et al., 2017; NCTM, 2018).

\section{Perceived behavioural control}

Our discussion of Knowledge of the approach (Theme 4) and Availability of the Resources (Theme 6) can be framed using the Perceived behavioural control component of Ajzen's (1991) TPB as they all relate to factors that enable a particular behaviour. In relation to the former theme (Knowledge of the approach), our finding highlights the importance of training teachers in how the use of story picture books supports the implementation of the mathematics curriculum, including the proficiencies of understanding, fluency, problemsolving and reasoning (ACARA, 2018). In relation to the latter theme, our findings highlight the value of schools providing teachers with appropriate resources, given that the existence of mathematical story picture books inspired teachers to teach mathematics using children's literature.

\section{Subjective norm}

The remaining theme, Enabling Social Norms, aligns with the Subjective norms, component of Ajzen's (1991) TPB as it relates to how a person's intention to behave in a certain way is shaped and influenced by what that person thinks about how others might perceive that behaviour. In the context of this study, a number of teachers felt inspired to teach mathematics using children's literature recommended by other teachers. By forming communities of practice (Wenger, 1999), teachers can learn from each other and inspire one another to enrich their mathematics teaching (e.g., Nickerson \& Moriarty, 2005). In light of this finding, there appears to be potential for such collaborations developing around the practices of using story books to extend children's mathematical understanding.

\section{Comparison of findings}

Our Australian study's findings largely resonate with those of the Irish study (Prendergast et al., 2019) and the Maltese study (Farrugia \& Trakulphadetkrai, 2020). Specifically, the contextual data of the teachers in this study revealed that the majority of them $(75.1 \%)$ had either never used children's literature in their mathematics teaching or had done so but infrequently (i.e., 10 mathematics lessons or less per school year). This self-reported contextual data is very much in line with what was reported for Maltese teachers $(79.4 \%)$, though not to the same extent as Irish teachers $(91.6 \%)$. That the majority of the teachers in the current study (and the other two studies) did not regularly enrich mathematics teaching and learning using story picture books is concerning, given the pedagogical benefits reported in research over the past three decades. 
Overall, the perceived barriers and enablers found in the Australian study also resonate with those found in Irish and Maltese studies. For example, the 'Encouraged and inspired by teacher's own perception that teaching mathematics through children's literature makes the teaching more engaging and fun' category is the most cited perceived enabler across all three studies, namely Australian (31\%), Irish (25.5\%) and Maltese (34.4\%). Similarly, the 'Limited or lack of awareness of suitable children's literature for specific mathematical concepts or age groups' category emerged as the most cited perceived barrier in the Australian study (31.5\%) and the Irish study (22.8\%), but appeared only as the fourth most cited perceived barrier in the Maltese study (13\%) behind Limited or lack of time (unspecified) (19.6\%); Curriculum pressure (15.2\%); and Limited or lack of suitable children's literature at school (15.2\%). While such nuanced differences in the emphasis in these perceived barriers and enablers exist across the national studies, the overall similarities in the emerging perceived barriers and enablers across the studies arguably highlight that teachers-regardless of where they teach—are constrained and enabled by similar forces.

\section{Conclusion and limitations}

The aim of this qualitative survey study of Australian primary school teachers was to investigate the range of key perceived barriers to, and enablers for, the integration of children's literature in mathematics teaching. A thematic analysis revealed 13 perceived barriers classified under five themes, with Lack of Pedagogical Knowledge and Confidence, and Time Constraint, representing $75 \%$ of all perceived barriers. 14 perceived enablers were identified and classified under five themes with Pedagogical Benefits and Love of Stories representing around $70 \%$ of all perceived enablers.

In terms of limitations, while our analysis of the study's open-ended survey data yielded a useful belief structure, we did not incorporate interviews as a data collection method, which likely would have provided further insights into some of the teachers' responses. Likewise, to corroborate some of the findings that emerged from the survey data, our findings may have been strengthened by observing some mathematics lessons where teachers used children's literature. Finally, we acknowledge that the use of snowball sampling with ISTs does not necessarily lead to representative results as teachers might have opted into the study due to their interest in teaching mathematics using story picture books.

Despite the above methodological limitations, we suggest that the current study is useful in highlighting to mathematics teacher educators and teacher training agencies in Australia, that it is likely that many Australian teachers are lacking the necessary pedagogical knowledge, experience and confidence to allow them to enrich their mathematics teaching with children's literature - an affordable pedagogical resource, which research over the past decades have consistently found to be beneficial. Teachers rely on their foundation knowledge, including beliefs about how mathematics should be taught (Rowland et al., 2009), which we suggest should include an awareness that using children's literature in mathematics teaching is beneficial. To ensure this, teachers could be provided with, for example, research-based evidence that extends their foundation knowledge and beliefs of how to plan mathematics lessons using story picture books. Further uptake could also be facilitated if teachers are provided with exemplars of best practice of other teachers effectively teaching with story picture books. Further research is still needed, including an investigation into whether teacher educators are reluctant to include the use of story picture books in their mathematics education course, using a research approach to the one reported here. 
Teacher educators could also consider the use of the TPB approach to capture barriers and enablers for this phenomenon as a means for identifying how to make (content-specific) teacher training more meaningful for ISTs and PSTs.

We hope this study will contribute to the existing international conversation regarding how PSTs and ISTs can be better prepared and supported in engaging children in mathematical experiences through the use of story picture books.

Acknowledgements We would like to thank the University of Reading for funding the Open Access fee for this article.

\section{Funding None.}

\section{Declarations}

\section{Conflict of interest None.}

Open Access This article is licensed under a Creative Commons Attribution 4.0 International License, which permits use, sharing, adaptation, distribution and reproduction in any medium or format, as long as you give appropriate credit to the original author(s) and the source, provide a link to the Creative Commons licence, and indicate if changes were made. The images or other third party material in this article are included in the article's Creative Commons licence, unless indicated otherwise in a credit line to the material. If material is not included in the article's Creative Commons licence and your intended use is not permitted by statutory regulation or exceeds the permitted use, you will need to obtain permission directly from the copyright holder. To view a copy of this licence, visit http://creativecommons.org/licenses/by/4.0/.

\section{References}

Ajzen, I. (1991). The theory of planned behavior. Organizational Behavior and Human Decision Processes, 50(2), 179-211.

Ajzen, I. (2020). The theory of planned behavior: Frequently asked questions. Human Behavior and Emerging Technologies, 2(4), 1-11. https://doi.org/10.1002/hbe2.195

An, S., Tinajero, J., Tillman, D., \& Kim, S. J. (2019). Preservice teachers' development of literacy-themed mathematics instruction for early childhood classrooms. International Journal of Early Childhood, 51(1), 41-57.

Anderson, A., Anderson, J., \& Shapiro, J. (2005). Supporting multiple literacies: Parents' and children's mathematical talk within storybook reading. Mathematics Education Research Journal, 16(3), 5-26.

Australian Curriculum Assessment and Reporting Authority (ACARA). (2018). The Australian Curriculum: Mathematics. Retrieved from http://www.australiancurriculum.edu.au/Mathematics/Curriculum/F-10.

Australian Bureau of Statistics. (2020). Schools. Retrieved from https://www.abs.gov.au/statistics/people/ education/schools/latest-release

Bintz, W. P., Moore, S. D., Wright, P., \& Dempsey, L. (2011). Using literature to teach measurement. The Reading Teacher, 65(1), 58-70.

Capraro, R. M., \& Capraro, M. M. (2006). Are you really going to read us a story? Learning geometry through children's mathematics literature. Reading Psychology, 27(1), 21-36.

Casey, B. M., Kersh, J. E., \& Young, J. (2004). Storytelling sagas: An effective medium for teaching early childhood mathematics. Early Childhood Research Quarterly, 19(1), 167-172.

Cotti, R., \& Schiro, M. (2004). Connecting teacher beliefs to the use of children's literature in the teaching of mathematics. Journal of Mathematics Teacher Education, 7(4), 329-356.

Edelman, J. (2017). How preservice teachers use children's literature to teach mathematical concepts: Focus on mathematical knowledge for teaching. International Electronic Journal of Elementary Education, 9(4), 741-752.

Edelman, J., Green, K. B., \& Jett, C. C. (2019). Children's literature to inform mathematics teaching and learning. A systematic review of the research literature from 1991-2016. The International Journal of Science, Mathematics and Technology Learning, 26(1), 49-60. 
Farrugia, M. T., \& Trakulphadetkrai, N. V. (2020). Maltese teachers' beliefs concerning the integration of children's literature in mathematics teaching and learning. Cogent Education. https://doi.org/10.1080/ 2331186X.2020.1817253

Flevares, L. M., \& Schiff, J. R. (2014). Learning mathematics in two dimensions: A review and look ahead at teaching and learning early childhood mathematics with children's literature. Frontiers in Psychology, 5, 1-10.

Fullan, M. (2015). The new meaning of educational change (5th ed.). Teachers' College Press.

Guskey, T. R. (1985). Staff development and the process of teacher change. Educational Leadership, 42(7), 57-60.

Halsey, P. (2005). Assessing mathematics tradebooks: Do they measure up? Reading Improvement, 42(3), 158-163.

Hassinger-Das, B., Jordan, N. C., \& Dyson, N. (2015). Reading stories to learn math: Mathematics vocabulary instruction for children with early numeracy difficulties. Elementary School Journal, $116(2), 242-264$.

Hong, H. (1996). Effects of mathematics learning through children's literature on math achievement and dispositional outcomes. Early Childhood Research Quarterly, 11(4), 477-494.

Kieran, C., Krainer, K., \& Shaughnessy, J. M. (2013). Linking research to practice: Teachers as key stakeholders in mathematics education research. In M. A. Clements, A. J. Bishop, C. Keitel, J. Kilpatrick, \& F. K. S. Leung (Eds.), Third international handbook of mathematics education. Springer international handbooks of education (pp. 361-392). Springer.

Kisker, E. E., Lipka, J., Adams, B. L., Rickard, A., Andrew-Ihrke, D., Yanez, E. E., \& Millard, A. (2012). The potential of a culturally based supplemental mathematics curriculum to improve the mathematics performance of Alaska Native and other students. Journal for Research in Mathematics Education, 43(1), 75-113.

Lincoln, Y., \& Cuba, E. (1985). Naturalistic inquiry. SAGE.

Marston, J. (2014). Identifying and using picture books with quality mathematical content. Australian Primary Mathematics Classroom, 19(1), 14-23.

Moyer, P. S. (2000). Communicating mathematically: Children's literature as a natural connection. The Reading Teacher, 54(3), 246-256.

Muir, T., Livy, S., Bragg, L., Clarke, J., Wells, J., \& Attard, C. (2017). Engaging with mathematics through picture books. Teaching Solutions.

Muir, T. (2018). Heads or Tails. Little Steps.

National Council of Teachers of Mathematics [NCTM] (1992). How to use children's literature to teach mathematics. NCTM.

National Council of Teachers of Mathematics [NCTM] (2004). Exploring mathematics through literature: Articles and lessons for prekindergarten through Grade 8. NCTM.

National Council of Teachers of Mathematics [NCTM] (2018). Deepening student's mathematical understanding with children's literature. NCTM.

Nickerson, S. D., \& Moriarty, G. (2005). Professional communities in the context of teachers' professional lives: A case of mathematics specialists. Journal of Mathematics Teacher Education, 8(2), 113-140. https://doi.org/10.1007/s10857-005-4795-8

Nurnberger-Haag, J. (2017). A cautionary tale: How children's books (mis)teach shapes. Early Education and Development, 28(4), 415-440.

Prendergast, M., Harbison, L., Miller, S., \& Trakulphadetkrai, N. V. (2019). Pre-service and in-service teachers' perceptions on the integration of children's literature in mathematics teaching and learning in Ireland. Irish Educational Studies, 38(2), 157-175. https://doi.org/10.1080/03323315.2018. 1484302

Purpura, D. J., Napoli, A. R., Wehrspann, E. A., \& Gold, Z. S. (2017). Causal connections between mathematical language and mathematical knowledge: A dialogic reading Intervention. Journal of Research on Educational Effectiveness, 10(1), 116-137.

Rogers, R. M., Cooper, S., Nesmith, S. M., \& Purdum-Cassidy, B. (2015). Ways that preservice teachers integrate children's literature into mathematics lessons. The Teacher Educator, 50(3), 170-186.

Rowland, T., Turner, F., Thwaites, A., \& Huckstep, P. (2009). Developing primary mathematics teaching: Reflecting on practice with the Knowledge Quartet. SAGE.

Russo, J., \& Russo, T. (2019). Investigations: Esio Trot. Prime Number, 34(2), 24.

Russo, T. (2018). Challenging task: Where the wild things are. Prime Number, 33(1), 16-19.

Russo, T., \& Russo, J. (2018). Narrative-first approach: Teaching mathematics through picture story books. Australian Primary Mathematics Classroom, 23(2), 8-14. 
Stites, M. L., Sonnenschein, S., Dowling, R., \& Gay, B. (2020). Mathematics learning opportunities in preschool: Where does the classroom library fit in? Early Education and Development. https://doi. org/10.1080/10409289.2020.1721403

Sullivan, P. (2018). Challenging mathematical tasks. Oxford University Press.

Sullivan, P., Mousley, J., \& Zevenbergen, R. (2006). Teacher actions to maximize mathematics learning opportunities in heterogeneous classrooms. International Journal of Science and Mathematics Education, 4(1), 117-143. https://doi.org/10.1007/s10763-005-9002-y

Thompson, A. G. (1984). The relationships of teachers' conceptions of mathematics and mathematics teaching instructional practice. Educational Studies in Mathematics, 15(2), 105-127.

Thompson, A. G. (1992). Teachers' beliefs and conceptions: A synthesis of the research. In D. A. Grouws (Ed.), Handbook of research on mathematics teaching and learning (pp. 127-146). Macmillan.

Trakulphadetkrai, N. V. (2015, September 15-17). The construction of the 'Primary Teachers' Beliefs concerning the Integration of Children's Literature in Mathematics Learning and Teaching' (PTBICLMLT) Framework: Findings from a pilot study. Paper presented at the British Educational Research Association (BERA) Annual Conference, Belfast, UK.

Trakulphadetkrai, N. V. (2018). Story picture books as a mathematics teaching and learning tool. Primary Mathematics, 22(2), 3-7.

Trakulphadetkrai, N. V., Courtney, L., Clenton, J., Treffers-Daller, J., \& Tsakalaki, A. (2020). The contribution of general language ability, reading comprehension and working memory to mathematics achievement among children with English as additional language (EAL): An exploratory study. International Journal of Bilingual Education and Bilingualism, 23(4), 463-487. https://doi.org/10.1080/13670050. 2017.1373742

van den Heuvel-Panhuizen, M., \& van den Boogaard, S. (2008). Picture books as an impetus for kindergartens' mathematical thinking. Mathematical Thinking and Learning, 10(4), 341-373.

Wenger, E. (1999). Communities of practice, learning, meaning and identity. Cambridge University Press.

Publisher's Note Springer Nature remains neutral with regard to jurisdictional claims in published maps and institutional affiliations.

\section{Authors and Affiliations}

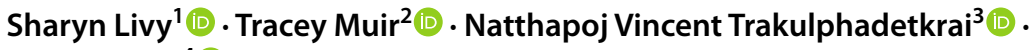 Kevin Larkin ${ }^{4}$}

Sharyn Livy

sharyn.livy@monash.edu

Tracey Muir

tracey.muir@utas.edu.au

Kevin Larkin

k.larkin@griffith.edu.au

1 Monash University, 47-49 Moorooduc Highway, Frankston, VIC 3199, Australia

2 University of Tasmania, Newnham Drive, Launceston, TAS 7250, Australia

3 University of Reading, 4 Redlands Road, Reading RG1 5EX, UK

4 Griffith University, 1 Parklands Drive, Southport, QLD 4215, Australia 